\title{
MOLECULAR IDENTIFICATION OF SPONGES OBTAINED FROM SERIBU ISLANDS NATIONAL PARK AND THEIR ASSOCIATED BACTERIA
}

\section{Identifikasi secara Molekuler Spons dari Kepulauan Seribu dan Bakteri yang Berasosiasi Dengan nya}

\author{
Gintung Patantis ${ }^{1 *}$, Gemilang Rahmadara ${ }^{2}$, Dewi Elfidasari ${ }^{2}$, and Ekowati Chasanah ${ }^{1}$ \\ ${ }^{1}$ Research and Development Center for Marine and Fisheries Product Processing and Biotechnology, \\ JI. K.S. Tubun Petamburan VI Jakarta Pusat 10260, Indonesia \\ ${ }^{2}$ Al Azhar Indonesia University, Kompleks Masjid Agung Al Azhar, Jakarta 12110, Indonesia \\ *Corresponding authors: gintung_p@yahoo.com \\ Article history: \\ Received 15 Oktober 2012, Received in revised form 7 Maret 2013, Accepted 8 Maret 2013
}

\begin{abstract}
Sponges are simple multicellular animals that produced many pharmaceutical secondary metabolites. Some sponge-associated bacteria are proven to produce the same metabolites as their host, giving an opportunity to mass produce the potential metabolites. The aim of this research was to analyze the diversity of sponge-associated bacteria and to identify the host sponge. Samples were collected from Seribu Islands National Park. Partial identification of sponges were conducted by molecular technique with the mitochondrial cytochrome oxidase subunit 1 (CO1) as the target area. The diversity of sponge-associated bacteria was determined by Terminal Restriction Fragment Length Polymorphism (T-RFLP) method. Result showed that sponges PS-17-12 has similarity with Petrosia sp., while PS-26-12 and PS-38-12 has similarity with Xestospongia muta. From the 3 sponge samples, 85 species of bacteria was obtained which can be classified into 9 phylums and 1 uncultured bacteria/environment sample. Some of the sponge-associated bacteria identified were known as a potential producer of metabolites with antibiotic activity.
\end{abstract}

Keywords: sponge, bacterial diversity, T-RFLP

\section{ABSTRAK}

Spons merupakan hewan multiseluler sederhana yang dapat memproduksi metabolit sekunder yang berpotensi sebagai senyawa farmasetika. Bakteri yang berasosiasi dengan spons diketahui juga menghasilkan metabolit yang sama, hal ini memberikan harapan untuk memproduksi secara masal metabolit potensial tersebut. Tujuan dari penelitian ini adalah untuk mengidentifikasi spons dan menganalisis keanekaragaman bakteri yang berasosiasi dengan spons. Sampel yang digunakan dalam penelitian ini diambil dari Taman Nasional Kepulauan Seribu. Identifikasi parsial spons dilakukan menggunakan teknik molekular dengan target daerah mitochondrial cytochrome oxidase subunit 1 (CO1) dan analisis keanekaragaman bakteri dengan metode Terminal Restriction Fragment Length Polymorphism (T-RFLP). Hasil penelitian menunjukkan bahwa spons PS-17-12; memiliki kemiripan dengan Petrosia sp., sementara PS26-12 dan PS-38-12 mirip dengan Xestospongia muta. Dari 3 sampel diperoleh 85 spesies bakteri dan dapat diklasifikasikan ke dalam 9 phylum dan 1 uncultured bacteria/ sampel lingkungan. Beberapa bakteri yang berasosiasi dengan spons dari Taman Nasional Kepulauan Seribu ini diketahui mempunyai potensi menghasilkan metabolit dengan aktivitas antibiotik.

Kata Kunci: spons, keanekaragaman bakteri, T-RFLP

Permalink/DOI: http://dx.doi.org/10.15578/squalen.v8i1.80

\section{INTRODUCTION}

Sponges are simple multicellular animals that are well known to producing more than 6000 secondary metabolites (Thomas et al., 2010). They produce the largest members of bioactive compound among the phylum Coelenterata, Tunicate and Bryozoans, many of them have pharmaceutical potency (Kijjoa \& Sawangwong, 2004; Thakur \& Muller, 2004). As filterfeeding organisms, sponges obtaining food by pumping large amounts of water through their cores and channels, so bacteria, single-cell algae and other food particles were filtered and many bacteria were inhabit and associated in their bodies (Taylor et al., 2007).

Identification of sponges is difficult, because sponges are morphologically indistinguishable, even with spicules identification. In addition, this technique is also difficult to see the relationship among species 
or evolutionary process, especially for taxa with small amounts species such as Halichondria. The utilization of additional characters, such as DNA barcodes and taxonomic system with a DNA sequence might provide an opportunity to understanding the evolutionary factors that shape species distributions in space and time (Worheide et al., 2007).

Furthermore, DNA barcoding has been established as an aid to increase the speed of sponge identification. Some areas or fragment DNA can be used for targeting DNA barcodes such as rDNA ITS, $18 S$ rDNA, the C2D2 region of the 28S rDNA and fragment mtDNA cytochrome oxidase subunit 1 (CO1). Fragment $\mathrm{CO} 1$ is used for almost all current (eukaryotic) barcoding initiatives which have 650 nucleotides. This mitochondrial fragmen has highly conserved COl-barcoding primers and easy to amplify DNA of sponge, the sequence displays sufficient variability in most bilaterian species. DNA barcoding date base has been set up for fragment $\mathrm{CO}$ at www.spongebarcoding.org (Worheide et al., 2007; Vargas et al., 2012; Gazave et al., 2013)

Many studies on microorganisms associated with sponges have been conducted using both culturedependent and culture-independent techniques. It was reported that sponges could contain bacteria up to $40 \%$ of the sponge volume (Wilkinson, 1978 in Thiel et al., 2006), helping the sponge removing waste and producing chemical defenses (Taylor et al., 2007). Associated bacteria has also been reported to produce the same metabolites with their host, opening an opportunity to mass produce potential active metabolites (Haygood et al., 1999). Study on the diversity of sponges associated bacteria and its ecological aspect is important to obtain initial data on metabolites discovery from sponges.

Culture-independent techniques have more advantages than culture-dependent to describe the bacterial diversity in the environment, one of them is T-RFLP that has been widely used to characterize the diversity of bacteria, fungi and functional gene (Tan et al., 2003; Genney et al., 2006; Hullar et al., 2006). Low price and able to analyze hundreds of samples per day are several advantages of this technique (Zhang et al., 2008).

Several studies have been conducted about sponges in Seribu Islands National Park, ranging from diversity (De Voogd \& Cleary, 2008), transplantation of sponges (Suparno et al., 2012), isolation of potential antitumor metabolites (Fajarningsih et al., 2006), isolation of protease inhibitor (Nurhayati et al., 2004), isolation of associated fungi from sponge (Fajarningsih et al., 2012). Study on bacterial diversity associated with Aaptos sp. has also been conducted
(Chasanah et al., 2013) but study on bacteria diversity associated with from Petrosia sp. and Xestospongia sp. has not been conducted.

The aim of this research was to analyze the diversity of bacteria community associated with three sponges that collected from Seribu Islands National Parks by T-RFLP technique and identification of the host sponge by molecular technique.

\section{MATERIALS AND METHOD}

\section{Sample Collection and Preparation}

Sponges samples were collected from Seribu Islands National Park waters from 5, 9 and $15 \mathrm{~m}$ depth, with sample code of PS-17-12; PS-38-12 and PS-2612. About $\pm 5 \mathrm{~g}$ of samples from 3 points of each depth were taken and stored in sterile bottle and stored at $-20^{\circ} \mathrm{C}$ until being processed in laboratory for analysis.

\section{DNA Extraction}

DNA extraction was conducted using Dneasy blood \& tissue kit (Qiagen). For spons identification, DNA extraction was conducted without pre-treatment following methods of Dneasy blood \& tissue kit (Qiagen) procedure, whereas for bacterial diversity DNA was extracted using destruction and centrifugation pretreatment (Bewley et al., 1996). Total samples of $\pm 0.1 \mathrm{~g}$ was needed for spons identifications, whereas for bacterial diversity analysis, it required $\pm 5 \mathrm{~g}$ of sponge samples. DNA extraction for T-RFLP was done following the Dneasy blood \& tissue kit (Qiagen) procedure. About $5 \mathrm{~g}$ of spons were blended until homogen and centrifuged at $200 \mathrm{x}$ g for 2 minutes at room temperature. The supernatant was transferred into new sterile microtubes and centrifuged at $400 \times \mathrm{g}$ for 2 minutes. Then the supernatant was transferred into a microtube and centrifuged at 10,000 $\mathrm{x} \mathrm{g}$ for $5 \mathrm{~min}$. Pellet from the last centrifugation was used for next procedure following Dneasy blood \& tissue kit (Qiagen) procedure. DNA was visualized on $1 \%$ agarose in $1 \times$ TBE buffer, which was visualized with SYBR-gold (Invitrogen).

\section{Identification of Sponge}

Identification of sponge was conducted based on molecular technique following Meyer et al. (2005) and Rot et al. (2006). Target area was the mitochondrial cytochrome oxidase subunit 1 (CO1) with a length of 640 base pairs (bp) and extended to $\pm 1,200 \mathrm{bp}$ (http:/ /www.spongebarcoding.org/). PCR was performed using 2 pairs of primers as shown in Table 1. 
Table 1. Primers used for sponges identification

\begin{tabular}{ccc}
\hline No & \multicolumn{1}{c}{ Primers sequence } & Reference \\
\hline 1 & dgLCO1490: GGT CAA CAA ATC ATA AAG AYA TYG G & Meyer et al. (2005) \\
& dgHCO2198:TAA ACT TCA GGG TGA CCA AAR AAY CA & \\
2 & COX1-R1: TGT TGR GGG AAA AAR GTT AAA TT & Rot et al. (2006) \\
& COX1-D2: AAT ACT GCT TT TाT GAT CCT GCC GG & \\
\hline
\end{tabular}

Sequencing analysis was conducted in $1^{\text {st }}$ Base Laboratory Singapore. Sequencing results were then analyzed by BioEdit Sequence Alignmen Editor 7.2.3 program for homology of sequencing results and Basic Local Alignment Search Tool (BLAST) program at http://blast.ncbi.nlm.nih.gov/. for similarity with species in data base.

\section{Bacterial Diversity of Sponges}

\section{$16 S$ rDNA Gene Amplification}

16S-rRNA gene was amplified using primers $27 \mathrm{~F}$ FAM (5 -CAGGCCTAACACATG CAAGTC-3), which was labeled with the phosphoramiditefluorochrome 5carboxyfluorescein (FAM) and 1387R (5GGGCGGAGTGTACAAGGC-3 ) (Marchesi et al., 1998). $25 \mu$ master mix was made with the following composition: $12.5 \mu \mathrm{l}$ Go taq green Master Mix 2x (Promega); $1 \mu$ l forward primer, $1 \mu \mathrm{l}$ reverse primer, $9.5 \mathrm{H}_{2} \mathrm{O}$; and $1 \mu$ template. PCR was performed at $95^{\circ} \mathrm{C}$ for $3 \mathrm{~min}, 30 \mathrm{cycles}$ of $95^{\circ} \mathrm{C}$ for $60 \mathrm{sec}, 55^{\circ} \mathrm{C}$ for $60 \mathrm{sec}$, and $72^{\circ} \mathrm{C}$ for $90 \mathrm{sec}$, followed by final extension $72^{\circ} \mathrm{C}$ for $20 \mathrm{~min}$. PCR products were visualized on $1 \%$ agarose gel in $1 \times$ TBE buffer.

\section{T-RFLP Analysis}

PCR products with fluorescent label were single digested with 3 restriction enzymes Msp1, Rsa1 and Cfo1. Digest reaction was consisted of $16 \mu \mathrm{l}$ of PCR products, $2 \mu \mathrm{l}$ restriction enzymes and $2 \mu \mathrm{l}$ of $10 \mathrm{x}$ restriction buffer and the mixture was incubated at $37^{\circ} \mathrm{C}$ overnight. Fragment was analysis was conducted in $1^{\text {st }}$ Base Laboratory Singapore. Fragment sizes were analyzed using FragSort ver.5.0 software with database from Microbial Community Analysis (http:// mica.ibest.uidaho.edu/) (Shyu et al., 2007).

\section{RESULTS AND DISCUSSION}

\section{Partial Identification of Sponges}

Sponges are multicelluler organism that highly diverse, abundant in almost every aquatic and important members of coral reef ecosystems (Van Soest, 1989; McClintock et al., 2005; Lesser, 2006). Identification of many sponges species is difficult, because they have similar morphology characters, even with spicules identification. Additional of DNA sequences information (DNA barcodes) are suggested to complete the identification (Worheide et al., 2007). In this study, the sponges identification was conducted with molecular technique (DNA barcodes).

Morphologically all samples were similar, i.e the surface color is maroon and cream in the inside (Figure 1). Analyzed with BioEdit, sequencing results from two pairs of primer (COX1-R1, COX1-D2 and dgLCO1490, dgHCO2198) showed that samples PS17-12 and PS-26-12 had 100\% homolog, on the other hand PS-38-12 had homology of $87.46 \%$ and $90.94 \%$ respectively with others. This indicated that in molecular level, samples PS-17-12 and PS-26-12 were the same species and PS-38-12 was different with others. This result was also confirmed by the BLAST analysis (Table 2).

Table 2 showed that PS-17-12 and PS-26-12 had similarity with Petrosia sp. and PS-38-12 with Xestospongia muta. The presence of length alignment from Petrosia sp. (43 and 44\%) was smaller than Xestospongia muta (93 and $97 \%$ ). This was presumably because the fragment from primers dgLCO1490 and dgHCO2198 were not yet available in data base. It was also reported by Montalvo \& Hill (2011) when identifying $X$. testudinaria, the CO1 fragments was not avaliable in the database. The use of molecular techniques for sponge identification is still limited, therefore some sequence did not exist in database. However the use of these techniques are continuing to grow. Petrosia sp. and Xestospongia muta are the same group belonging to Petrosiidae family (http://www.spongeguide.org). This family have characteristics as massive, vase-shaped or volcanoshaped sponges, sometimes encrusting, bulbous, and less commonly branching growth forms, stony, and brittle (Hooper \& Van Soest, 2002). De Voogd \& Cleary (2008) reported that Xestospongia and Petrosia sp. have been found in Seribu Island. 

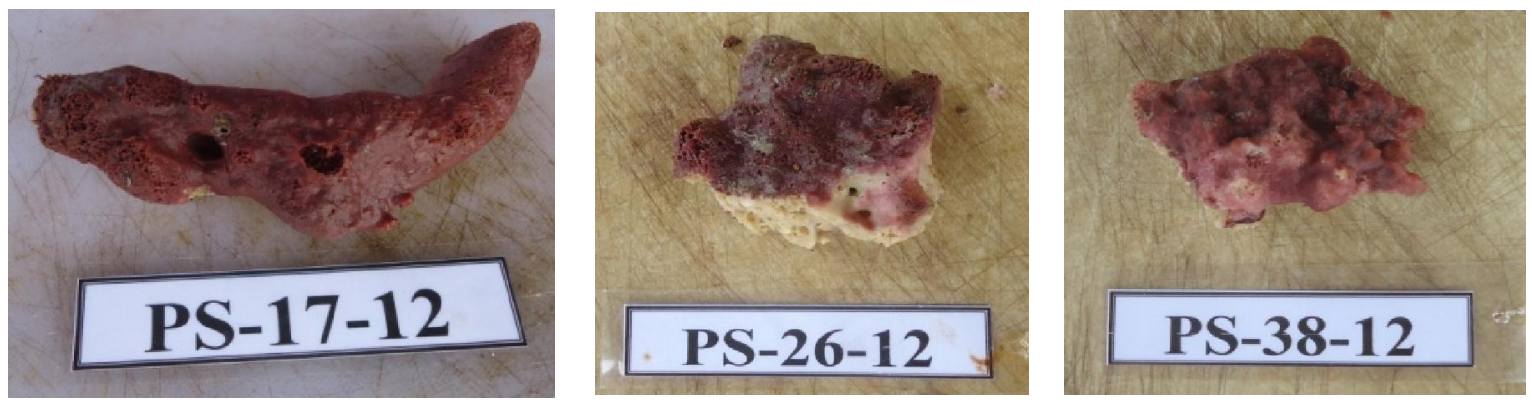

Figure 1. Sponge samples used in this research.

Table 2. Result of BLAST analysis of Sponge

\begin{tabular}{cclccc}
\hline No & Samples & Identification & Homology (\%) & Length alignment (\%) & Access Code \\
\hline 1 & PS-17-12 & Petrosia sp. & 100 & 44 & $\underline{\text { JN242217.1 }}$ \\
& & Xestospongia muta & 90 & 97 & $\underline{\text { HQ4522958.1 }}$ \\
2 & \multirow{2}{*}{ PS-26-12 } & Petrosia sp. & 100 & 43 & $\underline{\text { NN242217.1 }}$ \\
& & Xestospongia muta & 90 & 93 & $\underline{\text { HQ452958.1 }}$ \\
\multirow{2}{*}{3} & \multirow{2}{*}{ PS-38-12 } & Xestospongia muta & 99 & 97 & $\underline{\text { HQ452958.1 }}$ \\
& & Petrosia sp. & 100 & 44 & $\underline{\text { N242218.1 }}$ \\
\hline
\end{tabular}

\section{Diversity of Sponge-Associated BaCteria}

Analysis of $16 \mathrm{~S}$ gene is a common tool for studying phylogenetic, identification and assessing the diversity of bacteria. This gene having a size of 1,500 base pair (bp), can be found in all types bacteria, does not change, so that it can be used for evolution analysis (Case et al., 2007). Some techniques that are based on the 16S gene are denaturing gradient gel electrophoresis (DGGE) or temperature gradient gel electrophoresis (TGGE), single strand conformation polymorphism (SSCP), restriction fragment length polymorphism (RFLP) or amplified ribosomal DNA restriction analysis (ARDRA) and terminal restriction fragment length polymorphism (T-RFLP) which was used in this study (Liu et al., 1997; Muyzer \& Samalla, 1999; Kirk et al., 2004). The result of DNA extraction and amplification of $16 S$ gene of uncultured bacterial genes associated with sponges were presented in Figure 2.

Figure 2 showed that DNA extraction and amplification of $16 \mathrm{~S}$ was succesfully conducted resulting in clear bands (inside box) and no band for the negative control (line 4). The size of DNA is above
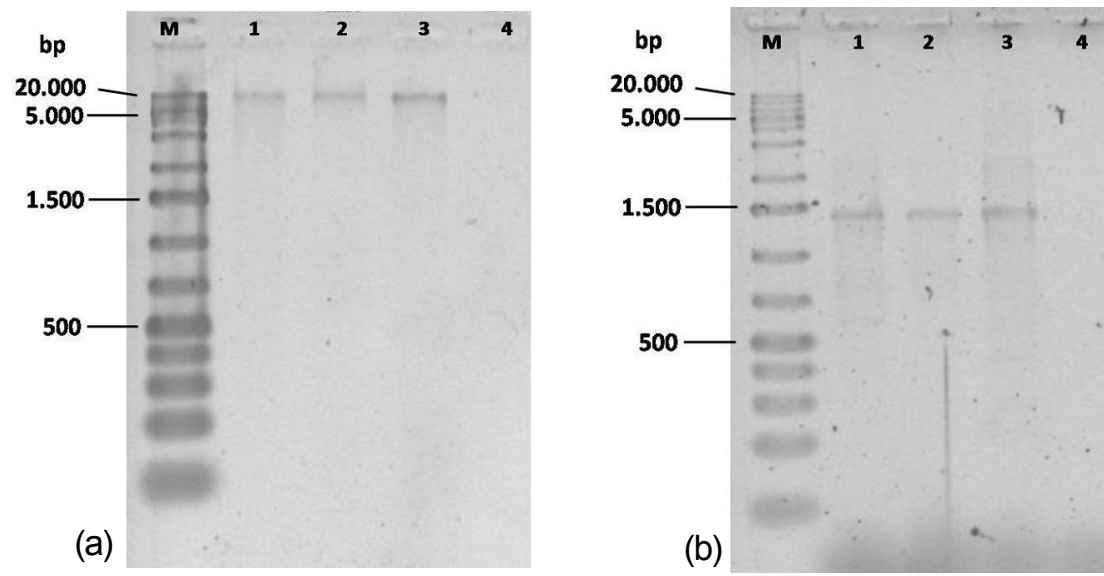

Figure 2. Result of DNA extraction (a) and amplification of $16 \mathrm{~S}$ gene (b) (Exp. M: GeneRuler 1 kb Plus DNA Ladder (Fermentas); 1 : PS-17-12; 2: PS-38-12; 3 : PS-26-12 and 4 : negative control). 


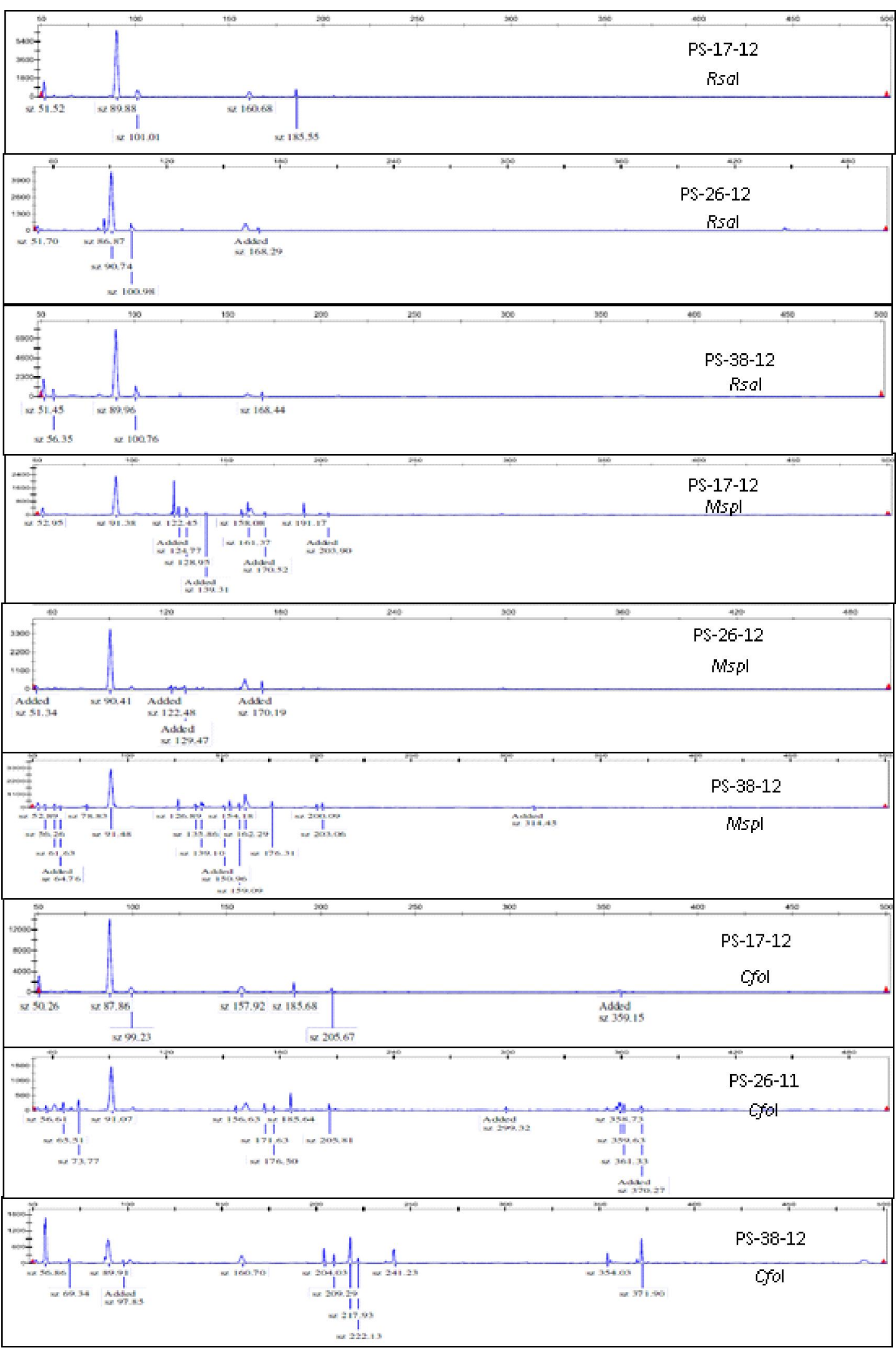

Figure 3. Electrogram graph of TRFLP analysis from samples PS-17-12; 2 : PS-26-12; 3 : PS-38-12 restricted with Msp1, Rsa1 and Cfo1. 


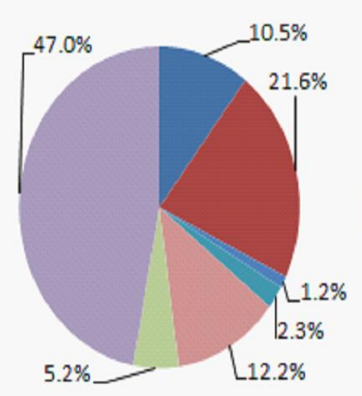

(A)

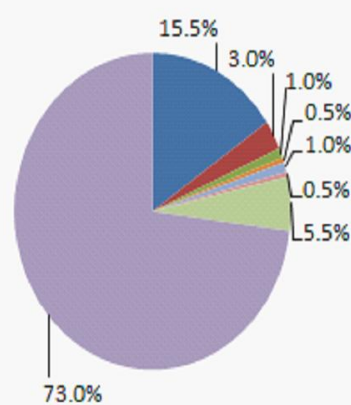

(B)

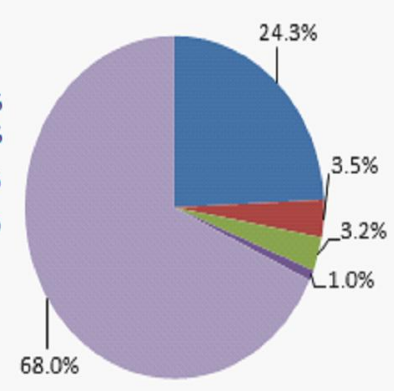

(C)

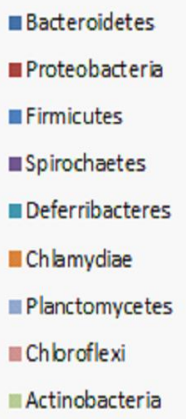

Euncultured bacteria

Figure 4. Percentage of bacterial communities found associated with. (A): PS-17-12; (B): PS-38-12; (C): PS-26-12.

$20,000 \mathrm{bp}$ and $16 \mathrm{~S}$ gene was approximately $\pm 1,300$ bp. The size of DNA from extraction in agarose is usually above the marker because the actual size of DNA genome is bigger than the marker. According to Vetrovsky \& Baldrian (2013) the size of bacterial genome ranged from $0.93 \mathrm{Mbp}$ to over 5.6 Mbp. The size of 165 gene from PCR was depending on the primer used. In this research, 27F and 1387R primer were used (the number is sequence from Escherichia coli), so the size of PCR product should be around -+ 1,300 bp (reduction of 1387 and 27).

T-RFLP analysis produced electrogram graph, consisting of $X$ and $Y$ axes. The $X$ showed the size of the fragment (base pair) and the $Y$ was the intensity of luminescence (Figure 3). The result of TRFLP was then analyzed using Fragsort 5.0 program, and Microbial Community Analysis (MICA) database in http://mica.ibest. uidaho.edu/ (Shyu et al., 2007).

The highest bacterial community was obtained from sponge PS-38-12 which had total number of 201 bacteria, followed by PS-17-12 and PS-26-12 with 172 and 96 numbers of bacteria, respectively. From the total numbers of bacteria (469) obtained, 85 species bacteria are environment samples could be classified into 9 phylum and 1 uncultured bacteria/ environment sample (Figure 4). There were Bacteroidates, Proteobacteria, Firmicutes, Spirochaetes, Deferribacteres, Chlamydiae, Planctomycetes, Chloroflexi, Actinobacteria and uncultured bacteria. Uncultured bacteria were dominated in all samples with more than $45 \%$ and then followed by Bacteroidates, Proteobacteria, and Actinobacteria. These phyla are commonly found associated with sponges (Li et al., 2006). The abundance of these bacteria in the sponges is related to its role in the carbon cycle of the ocean for organic compounds degradation (Bauer et al., 2006). The higher organic compounds in marine environment stimulated the abundance of bacterial communities that used organic compounds as nutrients for growth.

From partial identification result, samples PS-1712 and PS-26-12 were from the same sponges, i.e Petrosia sp., however the diversity of the bacteria associated with both samples was different . PS-1712 had more diverse bacterial community than that of PS-26-12, not only in number but also in phylum. These differences could be caused by their environmental condition. PS-17-12 has been harvested from depth 5 $\mathrm{m}$ while PS-26-12 was from $15 \mathrm{~m}$. White et al. (2012) reported that Axinella corrugata had several bacterial taxa communities that distinct when observed in different seasons sampling. Montalvo \& Hill (2011) reported that communities bacteria in two species Xestospongia (Xestospongia muta and $X$. testudinaria) taken from two different ocean were slightly different and the dominated bacteria are Chloroflexi, Acidobacteria, and Actinobacteria. In this research, group of Chloroflexi was also found in sponge Petrosia sp. Spirochaetes only found in PS-26-12 taken from $15 \mathrm{~m}$. This is because of this phylum was known as anaerob facultative can live either in the presence or absence of oxygen. Therefore, the presence of this bacterial communities can be related with the oxygen content in waters (Canale-Parola, 1977, 1984 in Hoover et al., 2003). Environmental conditions (spatial and temporal) can affect bacterial community in sponges. The results showed that the same sponges might have different bacterial community.

Xestospongia sp. has been reported as a bioactive compounds producer such as xestospongin, sterols, renieramycin (Darumas et al., 2007), and menzamines, aaptamines (Thomas et al., 2010) which posseses anti-cancer, anti-microbial and cytotoxic activity (Nakamura, 2005). Meanwhile, these 
secondary metabolites are also obtained from microbes associated with sponges. Triclosan and lutoside that have antibacterial activities have been extracted from Micrococcus luteus (Actinobacteria), which was isolated from Xestospongia sp. (BultelPonce et al., 1998). Fungus from Xestospongia sp. and Petrosia sp. also produce secondary metabolite that have antibacterial, antifungal and melanin inhibitor activities (Thomas et al., 2010). In their research, Actinomadura oligospora that had antibiotic activity, has been detected; while the presence of Capnocytophaga sp. was reported to have betalactamase enzyme (Mertz \& Yao, 1986; Foweraker, et al., 1990). Proteobacteria, Bacteroidetes, Firmicutes and Actinobacteria were also found and dominated in all samples. These phylum produce secondary metabolites that have antimicrobial activity, antiangiogenic and cytotoxic (Thakur et al. 2005).

\section{CONCLUSION}

Sponges PS-17-12 and PS-26-12 were identified as Petrosia sp while PS-38-12 had similarity with Xestospongia muta. From the total numbers of bacteria associated with those sponges (469), 85 species bacteria were including as environment at samples could be classified into 9 phylum and 1 uncultured bacteria/ environment sample, were are Bacteroidates, Proteobacteria, Firmicutes, Spirochaetes, Deferribacteres, Chlamydiae, Planctomycetes, Chloroflexi, Actinobacteria and Uncultured bacteria. Each sample has little different of bacteria community with others. PS-38-12 has the highest community followed by PS-17-12 and PS-2612. Some these sponges-associated bacteria were well known to have potential in producing metabolites with antibiotic activities.

\section{REFERENCES}

Bauer, M., Kube, M., Teeling, H., Richter, M., Lombardot, T., Allers, E., and Glockner, F.O. 2006. Whole genome analysis of the marine Bacteroidetes 'Gramella forsetii' reveals adaptations to degradation of polymeric organic matter. Environ. Microbiol. 8 (12): 2201-2213.

Bewley, C.A., Holland, N.D., and Faulkner, D.J. 1996. Two classes of metabolites from Theonella swinhoei are localized in distinct populations of bacterial symbionts. Experientia. 52: 716-722.

Bultel-Ponce, V., Debitus, C., Berge, J. P., Cerceau, C., and Guyot, M. 1998. Metabolites from the spongeassociated bacterium Micrococcus luteus. J. of Mar. Biot. 6: 233-236.

Case, R.J., Boucher, Y., Dahllof, I., Holmstrom, C., Doolittle, W.F., and Kjelleberg, S. 2007. Use of 16S rRNA and rpoB genes as molecular markers for microbial ecology studies. Appl. Environ. Microbiol. 73: 278-88.

Chasanah, E., Patantis, G., Dewi, A.S., Marraskuranto, E., Januar, H.I., Stella, S., and Yogiara. 2013. Analysis of bacterial community associated with Aaptos sp. from Rote and Seribu Islands. Microbiol. Indonesia. 7(1): 37-44.

Darumas, U., Chavanich, S., and Suwanborirux, K. 2007. Distribution patterns of the renieramycin-producing ponge, Xestospongia sp., and its association with other reef organisms in the gulf of Thailand. Zoological Studies. 46: 695-704.

De Voogd, N.J. and Cleary, D.F. 2008. An analysis of sponge diversity and distribution at three taxonomic levels in the Thousand Islands/Jakarta Bay reef complex, West Java, Indonesia. Mar. Eco. 29 (2): 205215

Fajarningsih, N.D., Januar, H.I., Nursid, M., dan Wikanta, T. 2006. Potensi antitumor ekstrak spons Crella papilata asal Taman Nasional Laut Kepulauan Seribu. J. Pascapanen dan Biotek. Kel. dan Perik. 1(1): 36-42.

Fajarningsih, N.D., Pratitis, A., Wikanta, T., dan Chasanah, E. 2012. Bioprospeksi kapang yang berasosiasi dengan biota laut asal Kepulauan Seribu sebagai antitumor T47D dan HepG2. J. Pascapanen dan Biotek. Kel. dan Perik. 7(1): 21-30.

Foweraker, J.E., Hawkey, P.M., Heritage, J.O.H.N., and Van Landuyt, H.W. 1990. Novel beta-lactamase from Capnocytophaga sp. Antimicrobial Agents and Chemotherapy. 34(8): 1501-1504.

Gazave, E., Lavrov, D.V., Cabrol, J., Renard, E., Rocher, C., Vacelet, J., Adamska, M., Borchiellini, C., and Ereskovsky, A.V. 2013. Systematics and molecular phylogeny of the family oscarellidae (homoscleromorpha) with description of two new oscarella species. PloS one. 8(5): e 63976.

Genney, D.R., Anderson, I.C., and Alexander, I.J. 2006. Fine-scale distribution of pine ectomycorrhizas and their extramatrical mycelium. New Phytol. 170: 381390.

Haygood, M.G., Schmidt, E.W., Davidson, S.K., and Faulkner, D.J. 1999. Microbial symbionts of marine invertebrates: opportunities for microbial biotecnology. Mol. Microbiol. and Biotechnology. 1(1):33-43

Hooper, J.N.A. and Van Soest, R.W.M. 2002. Systema Porifera. Guide to the supraspecific classification of sponges and spongiomorphs (Porifera). Plenum, New York.

Hoover, R.B., Pikuta, E. V., Bej, A. K., Marsic, D., Whitman, W. B., Tang, J., and Krader, P. 2003. Spirochaeta americana sp. nov., a new haloalkaliphilic, obligately anaerobic Spirochaete isolated from soda Mono Lake in California. Inter. J. of Systematic and Evolutionary Microbiology. 53(3): 815-821.

Hullar, M.A.J., Kaplan, L.A., and Stahl, D.A. 2006. Recurring seasonal dynamics of microbial communities in stream habits. Appl. Environ. Microbiol. 72: 713-722.

Kijjoa, A. and Sawangwong, P. 2004. Drugs and cosmetics from the Sea. Mar. Drugs. 2: 73-82. 
Kirk, J.L., Beaudettea, L.A., Hartb, M., Moutoglisc, P., Klironomosb, J.N., Leea, H., and Trevorsa, J.T. 2004. Methods of studying soil microbial diversity. J. of Microbiol. Methods. 58: 169- 188.

Lesser, M.P. 2006. Benthic-pelagic coupling on coral reefs: feeding and growth of Caribbean sponges. $J$ Exp. Mar. Biol. Ecol. 328: 277-288.

Li, Z.Y., He, L. M., Wu, J., and Jiang, Q. 2006. Bacterial community diversity associated with four marine sponges from the South China Sea based on 16S rDNA-DGGE fingerprinting. J. of Experim.Mar. Biology and Ecology. 329(1): 75-85.

Liu, W.T., Marsh, T.L., Cheng, H., and Forney, L.J., 1997. Characterization of microbial diversity by determining terminal restriction fragment length polymorphisms of genes encoding 16S rRNA. Appl. Environ. Microbiol. 63: 4516-4522.

Marchesi, J.R., Sato, T., Weigtman, A.J., Martin, T.A., Fry, J.C., Hiom, S.J., Dymock, D., and Wades, W.G. 1998. Design and Evaluation of Useful Bacterium-Specific PCR Primers That Amplify Genes Coding for Bacterial 16S rRNA. Appl. Environ. Microbiol. 64: 795-799.

McClintock, J.B., Amsler, C.D., Baker, B.J., and Van Soest, R.W.M. 2005. Ecology of Antarctic Marine Sponges: An Overview. Integr. Comp. Biol. 45: 359-368.

Mertz, F.P. and Yao, R.C. 1986. Actinomadura oligospora sp. nov., the producer of a new polyether antibiotic. Inter. J. of Systematic Bacteriology. 36(2): 179-182.

Meyer, C.P., Geller, J.B., and Paulay, G. 2005. Fine scale endemism on coral reefs: Archipelagic differentiation in turbinid gastropods. Evolution. 59: 113-125.

Montalvo, N.F. and Hill, R.T. 2011. Sponge-associated bacteria are strictly maintained in two closely related but geographically distant sponge hosts. Applied and Environ. Microbiol. 77 (20): 7207-7216.

Muyzer, G. and Smalla, K. 1999. Application of denaturing gradient gel electrophoresis (DGGE) and temperature gradient gel electrophoresis. Microbial Ecol. 73: 127-141.

Nakamura, M., Kakuda, T., Qi, J., Hirata, M., Shintani, T., Yoshioka, Y., Okamoto, T., Oba, Y., Nakamura, H., and Ojika, M. 2005. Novel Relationship between the Antifungal Activity and Cytotoxicity of Marine-Derived Metabolite Xestoquinone and It's Family. Biosci. Biotechnol. Biochem. 69: 1749-1752.

Nurhayati, T., Suptijah, P., Suhartono, M.T., dan Febrian, I. 2004. Penapisan inhibitor protease yang dihasilkan oleh sponge asal Kepulauan Seribu. Bul. Tekn. hasil Perik. 8(2): 45-59.

Rot, C., Goldfarb, I., Ilan, M., and Huchon, D. 2006. Putative cross-kingdom horizontal gene transfer in sponge (Porifera) mitochondria. Bmc Evolutionary Biology. 6: 71. doi: 10.1186/1471-2148-6-71.
Suparno, S., Soedharma, D., Zamani, N.P., dan Rachmat, R. 2012. Transplantasi spons laut Petrosia nigvicans. Indonesian Journal of Marine Science, 14(4): 54-61.

Shyu, C., Soule, T., Bent, S.J., Foster, J.A., and Forney, L.J. 2007. MiCA: A Web-Based Tool for the Analysis of Microbial Communities Based on TerminalRestriction Fragment Length Polymorphisms of $16 \mathrm{~S}$ and $18 \mathrm{~S}$ rRNA Genes. J. of Microbial. Ecology. 53: $562-570$.

Tan, X.Y, Hurek, T., and Reinhold-Hurek, B. 2003. Effect of N-Fertilization, plant genotype and environmental conditions on nifh gene pools in roots of rice. Environ Microbiol. 5: 1009-1015.

Taylor, M.W., Radax, R., Steger, D., and Wagner, M. 2007. Sponge-associated microorganisms: evolution, ecology, and biotechnological potential. Microbiol. Mol. Biol. Rev. 71: 295.

Thakur, N.L. and Muller, W.E.G. 2004. Biotechnological potential of marine sponges. Current Science. 86 (11): 1506-1512.

Thiel, V., Neulinger, S.C., Staufenberger, T., Schmaljohann,R. and Imhoff, J.F. 2006. Spatial distribution of sponge-associated bacteria in the Mediterranean sponge Tethyaaurantium. FEMS Microbiol. Ecol. 59(1): 47-63. xx : 1-11.

Thomas, T.R.A., Kavlekar, D.P., LokaBharathi, P.A. 2010. Marine drugs from sponge-microbe association: a review. Mar. Drugs. 8: 1417-1468.

Van Soest, R.W.M. 1989. The Indonesian Sponge Fauna: A Status Report. Netherlands Journal Of Sea Research. 23(2): 223-230.

Vargas, S., Schuster, A., Sacher, K., Büttner, G., Schatzle, S., Lauchli, B., and Worheide, G. 2012. Barcoding Sponges: An Overview Based on Comprehensive Sampling. PloS one. 7(7): e39345.

Vetrovsky, T. and Baldrian, P. 2013. The variability of the 16S rRNA gene in bacterial genomes and its consequences for bacterial community analyses. Plos One. 8(2): 1-10.

White, J.R., Patel, J., Ottesen, A., Arce, G., Blackwelder, P. and Lopez, J.V. 2012. Pyrosequencing of bacterial symbionts within Axinella corrugata sponges: diversity and seasonal variability. PloS one. 7(6): e38204.

Worheide, G., Erpenbeck, D., and Menke, C. 2007. The Sponge barcoding project: aiding in the identification and description of poriferan taxa. Porifera research: Biodiversity, innovation and sustainability: 123-128.

Zhang, R., Thiyagarajan, V., and Qian, P.Y. 2008. Evaluation of terminal-restriction fragment length polymorphism analysis in contrasting marine environments. FEMS Microbiol. Ecology. 65: 169178. 